\title{
Speech Function in E-Talk Show Program
}

\author{
Berlin Sibarani \\ English Applied Linguistics Study \\ Program Postgraduate School University of Medan \\ Medan, Indonesia
}

\author{
Didik Santoso \\ English Applied Linguistics Study \\ Program Postgraduate School University of Medan \\ Medan, Indonesia
}

\begin{abstract}
The choice of speech functions and the mood realization are part of the interpersonal functions which can influence the interpersonal relationship between the speakers in a conversation. The objectives of this study are to describe kinds of speech functions found in the guest utterances in E-talk show. The research applies qualitative content analysis method. The sources of data are the host and the guests in E- talk show program on TvOne. The data of the study are part of conversation utterances of from the guests in E- Talk Show. As the result, the research found that, the speech functions occur in the guests' utterances in both in the sensitive topics are statement, question, command, and coffer. However, Command was not found in opponent side. When talking about sensitive topics, interrogative mood is mostly used indirectly to give the information as statement of speech function. The guest also tended to command before giving some statement to avoid or to disclaim the host in pursuit more information related to the host assumption.
\end{abstract}

\section{Keywords: Speech Function, E-Talk Show}

\section{INTRODUCTION}

Talk show is one of the situations where conversation or dialog takes place. According to Timberg, 2002:5, a talk show or known also as chat show is a program where one person (or group of people) will discuss various topics which are leaded by a talk show host. These features pertain with conversational discourse. In talk show, the participants are usually stimulated, guided and facilitated by the host to present particular information exchange, related to personal experience, judgment or common sense. By this explanation it is obvious that in talk show language serve two of its interpersonal functions. The E-talk show is the program broadcasted ranges from politics, family matters, economics, music, etc. comes with a talk show format to review about the unpublished story of famous person and offered by relax in that situation. The program which has aired since August 9, 2017 is a new entertainment program in TvOne. E-talk show has invited guests which are celebrities, singers, musician, politician, and has different topic in different episode. This speech function is used to express the speaker's ideas or to convince and receive that information. The conversation transcript contains a dialogue between two people in each show; they are the host and the guest. In line to these phenomena, this study aims to identify any kinds of speech functions found in the guest utterances in E-talk show in term of political conversation.

\section{REVIEW OF RELATED LITERATURE}

Speech functions are the actions or performance done by language users as asking, commanding and answering in order to fulfill the intention of the speakers and listener (Halliday, 1994:30). Speaker function is the speaker's role in communicative exchange. It implies that form of actions; the speaker or writer is doing something to the listener reader by a means of language. To build an interaction with other people, the speaker uses the four specific forms: statements, questions, offers and commands or termed as Speech Functions. Speech functions can be defined as meaning addressed to the interactants/participants conveying the roles taken and commodity given. Whenever two persons or more use language to interact, one of the things they do with it is establishing a relationship between them. It means that there are two most fundamental types of speech roles: (1) giving and (2) demanding (Halliday, 1994:69). On the other hand, proposals cannot be argued about affirmed or denied rather than the addressee or listener can decide to accept or refuse the goods and services offered. In doing communication, the speaker performs a particular speech function and in so doing assigns to the listener a complementary function which the speaker wishes the listener to perform in his turn. For example, in asking a question, a speaker is taking on the role of seeker information and requiring the listener to take on the function of supplier of the information demanded. The commodity being exchanged may be either information or goods and services. The elaboration of the speech function and the commodity exchanged can be seen from the table below.

\begin{tabular}{|l|l|l|}
\hline \multirow{2}{*}{$\begin{array}{l}\text { Speech } \\
\text { Functions }\end{array}$} & \multicolumn{2}{|l|}{ Commodity Exchanged } \\
\cline { 2 - 3 } & Information & Good \& service \\
\hline & $\begin{array}{l}\text { 1. Statement } \\
\text { I helped my mother } \\
\text { yesterday. }\end{array}$ & $\begin{array}{c}\text { 3. Offer } \\
\text { Would you like } \\
\text { any help? }\end{array}$ \\
\hline Demanding & $\begin{array}{l}\text { 2. Question } \\
\text { Did you help your } \\
\text { mother? }\end{array}$ & $\begin{array}{c}\text { 4. Command } \\
\text { Help me! }\end{array}$ \\
\hline \multicolumn{2}{|c|}{ Source: (Halliday, 1994:69) } \\
\hline
\end{tabular}

From the table above, these two variables (speech functions and commodity exchanged) when taken together, define the four primary speech functions, namely, statement, 
question, offer and command that realized by Mood to perform two functions, they are giving and demanding. With reference to systemic functional linguistics theories, as developed by Halliday (1994:69) and other systemics's, the four speech functions can be briefly concluded as follows:

$\begin{array}{lll}\text { 1. } & \text { Giving/Information } & =\text { Statement } \\ \text { 2. } & \text { Demanding/Information } & =\text { Question } \\ \text { 3. } & \text { Giving/Goods } & =\text { Offer } \\ \text { 4. } & \text { Demanding/Goods \& Services } & =\text { Command }\end{array}$

In addition, political speech can be classified as a persuasive speech since it contains information to help people make a decision. The purpose of a persuasive speech itself is to persuade people to change in some way. For example, it could be to change the way they think about something or it could be to change the way they do things. Finally, it could be to persuade the audiences to do something that they do not do now. The speech will be successfully if at end of it, the audience is willing to make the change suggested. Speech has many purposes; to inform, to persuade and to entertain. The researcher chooses the supporter's speech and opponent's speech of government of Jokowi. In this case, political speech from the both of speeches. The researcher chooses the both of speeches because those speeches attracted many attentions from audience so it will be useful for the contribution of creating a powerful political speech which can attract many attentions from public.

\section{RESEARCH DESIGN}

This study applied qualitative descriptive designs. According to Bogdan and Biklen (1992:30), qualitative research is descriptive, about what going on and what data shows. The data were collected in the form of words or pictures rather than numbers. The data can be taken from interview, field note, photo, videotape, private document, note, memo and other official records. This study tried to analyze the interpersonal metafunctions in terms of speech functions in guest's utterances. In addition, the data of this study were collected by applying a documentary technique, a method for collecting the data which is kept in the form of documentation. To collect the data, the researcher downloaded the videos in cite of www.youtube.com and scripts of the speeches from the utterances participants as interviewees(guest) in E-Talk Show Program on tvOne. In analyzing the data of the study, Miles, Huberman and Saldana techniques (2014) were uses. Miles, Huberman and Saldana elaborated some steps of analyzing data, they are: (1) data condensation (2) data display (the step to show/make the visual of the data in the form of chart, diagram, matrix, or graphic) and (3) data verification/conclusion (the last step to draw conclusion from the data shown in the data display).

\section{RESEARCH FINDING AND DISCUSSION}

Political speech is a kind of powerful weapon for the politician to win over public's hearts, to influence and to persuade the audience. In delivering the speeches, the politicians do more than talk: they interact with language and employ it to express interpersonal meanings. It means that the language is used to establish and maintain the social relation between the host and the guest. as stated by Halliday (2004), when we communicate, we use language more than just to speak but to enacting and maintain interpersonal relations, and it is done by taking a particular role when in the speaking, whether we are demanding, giving, initiating or responding. These roles affect the politician's choice of speech functions. There were two kinds of utterances analyzed in this research. They were utterances' supporter of Jokowi and utterances' opponent of Jokowi. Having analyzed the data, there were four types of speech functions found in the speech. They were statement, command, offer and greeting/call.

\section{A. Statement}

Statement as a speech function has a purpose to give information. This speech function is used to express the speaker's ideas or to convince and receive that information. The conversation transcript contains a dialogue between two people in each show; they are the host and the guest. After analyzing the conversation transcript, the researcher finds out that the commodity mostly exchanged both the supporter and the opponents are the (statement) information. There are 407 statements in the conversation transcript from supporters and 369 referred to opponents. It indicates that the both sides who produce the highest number of speech function "statement" are the supporters. They are the dominant speaker who plays the role as the giver by giving some information. By referring to this finding, the data analysis found out that statement is used in the E-Talk Show as seen in data 1 and 2.

a. Supporter's utterances

Data 1:

Host : Jadi, sibuk apa sekarang ni? ( so, what are you doing now?)

Guest $\quad$ : Aku banyak bantuu ee menko maritim pak luhut binsar panjaitan

( I am more helping economic ministry, $\mathrm{Mr}$. Luhut Binsar Panjaitan)

Host : OK

(okay)

Guest $\quad$ : ya, karna kami tim sukses dulu dari bravo 5 mendukung pak Jokowi, pak Yusup Kalla. (Yea, because we are the succeed Team of bravo 5, supporting Mr. Jokowi, Mr. Yusuf Kalla)

(App2/P172-173/U39-44)

b. Opponent's utterances

Data 2:

Host : Jadi,,hehehe jadi ada feedback memang? (so, there is a feedback maybe?)

Guest: Yaa bagus-bagus aja saya kira, kan namanya komunikasi dan melalui seni kan komunikasinya yaaa jauh lebih cerdas lah

(okay, I think it is good, that is a communicated and art isn't, the communication is more intelligent)

Host : Ya.. ya.. (okay, okay)

Guest : Kalo ada yang begitu saya kira bagusbagus aja 
(I think it will be okay)

\section{B. Question}

In the conversation, question as a speech function has a purpose to demand information. There are interesting things that can be spotlighted in this section, the supporters were still more dominant in giving questions then the opponents. However, the questions of supporters were not addressed to the host, but to themselves, where they asked for themselves as a part of the explanation and answer as a part of the clarification. Unlike the supporters, the opponents only answer the questions from the Host, although the questions are obtained from their dialogue, but the questions are clearly addressed to the Host or audience. By referring to this finding, the data analysis found out that question is used in the E-Talk Show as seen in data.

Data 3:

$$
\text { a. Supporter's utterances }
$$

Host : masih gak demokrat? (are you still in democrat?)

Guest : saya masih kader demokrat (I am still in democrat)

Host : oh, Masih (ouh you are)

Guest: Tapi.. saya tidak mau lagi aktif di politik... (but, I won't be active in politics)

Host $: \mathrm{Oh}$ (ouh)

Guest

: dan bahkan DPR pun kan saya mundur. Kenapa...? karna pada waktu itu, saya diminta ee jangan dukung salah satu calon tapi dukung putra ketua umum saya.

(I even resigned the DPR. Why...? because at that time, I was asked that don't support one of the candidates, but support my general chairman's son).

Data 3

Shows that speech function 'question' which is used by Guest is demanding information from himself. The utterance "Why?" in turn means that te Guest asks himself about his reason resigned from DPR. In other words, it describes that the Guest invites himself to provoke some information.

Data 4:

Guest: karakter itu penting mas wahyu? Yang ketiga tadi sehat. Sehat itu bukan hanya sehat fisik tapi mentally juga sehat gitu ya.

(Is character important, Mas Wahyu? The third was healthy. Healthy is not only healthy physically but mentally is also healthy)

Host : Iya ya, betul ya!

(oh yes, that is true)

Data 4 shows that speech function 'question' which is used by the Guest is demanding information from Mas Wahyu. The utterance "Is character important, Mas Wahyu?" in means that the guest asks the host about character. However, the guest did not give opportunities to the Host to answer the question. He keeps continuing his explanation. It indicates that the question seems to be a stressing idea.
Data 5:

b. Opponent's utterance

Host : Tapi kan Islam sudah familiar, tidak ada yang berbeda!

(But Islam has already been famous, nothing different!)

Guest $\quad$ Kenapa anda berfikir demikian? (Why do you thing like that?)

Data 5 shows the guest can move or turn to ask question to the host.

\begin{tabular}{|c|c|c|c|c|}
\hline \multirow{2}{*}{ No } & \multirow{2}{*}{$\begin{array}{l}\text { Types of } \\
\text { Speech } \\
\text { Function }\end{array}$} & \multicolumn{2}{|c|}{ Frequency } & \multirow{2}{*}{ Total } \\
\hline & & Supporters & Opponents & \\
\hline 1 & Statement & 270 & 214 & 484 \\
\hline 2 & Question & 25 & 6 & 31 \\
\hline 3 & Command & 7 & 3 & 10 \\
\hline 4 & Offer & 6 & 1 & 7 \\
\hline \multicolumn{4}{|c|}{ Total } & 532 \\
\hline
\end{tabular}

\section{Command}

As a speech function, command has the purpose to demand goods and services in a conversation. It can be said that command function is to ask someone to do something. The commodity exchange in a command is good and services. In the conversation transcript, the researcher finds 2 commands as speech functions only from supporters.

a. Supporter's utterance

Data 6:

Host : Kan orang kecewa wajar... (Disappointing is normal)

Guest : Dengar..., dengar baik-baik! Pada waktu itu saya diberikan kepercayaan oleh Golkar. (Listen, Listen Carefully! When I was elected by Golkar .....)

Data 7 :

Host : Tapi...

Guest : Dengar dulu, Dengar baik-baik! Seorang Umar Ibnu Khattab ...

(Listen, Listen Carefully!, an Ibnu Umar Khattab .....)

It can be seen that the Guest try to demand the conversation, he gave the command in order to make the host pay attention on what he said.

\section{Offer}

Offer occurs when the speaker gives the hearer some goods or service and the speaker inherently invites the hearer to receive those goods and service. The speech function 'offer' which are produced by both sides are as follows: 
Data 8:

\section{a. Supporter's utterance}

Host: Seberapa dekat sih seorang ali mochtar ngabalin dengan presiden?

(How close You (Ali Mochtar) to the President?)

Guest: Datang ke istana dan tidak usah kasih kabar saya

(Visit the presidential palace without any confirmation so that you can see how....)

\section{Table 4.1 Speech Functions used in E-Talk Show}

The speech functions occur in the guests' utterances in both in the sensitive topics are statement, question, command, and offer. However, Command was not found in opponent side. From the explanation of the previous data analysis, it can be seen that there are several speech functions found out in the host's utterances, namely, statement, question, command, offer, acknowledgement, answer, and contradiction, where statements most dominantly occurred which are realized in the mood of tagged declarative. This indicates that the host's already knew the fact or information about the guests very well, but he also attempts to get the agreement or confirmation from the guests by realizing his statements in mood of tagged declarative. This finding is not in line with the theories in the previous research that stated questions are central to the structure of talk shows and are quite effective in exploring guests' professional and personal lives (Munson, 1993), In fact, from what the host of E- Talk Show did by giving statement to his guests in tagged declarative mood causes the guests to acknowledge the statements and leads them to give some more explanation or additional information. The use of statements which realized in tagged declarative mood also is also the way of the host to ask questions in indirect way.

In the guests' utterances it is also found out that statements most dominantly occurred which are realized in the declarative mood. Unlikely the host's statements which are realized in the tagged declarative mood which still needs confirmation or agreement from the guests, the guests realize their statements in declarative mood which explains that they give the information without attempting to invite the host to give the confirmation or the agreement to what they state. This also indicates that the guests are the source of information in the talk show. Statement belongs to initiating speech functions; therefore, the use of statements by the guests mostly in their utterances shows us that they are given rights to initiate the topic they want to talk about.

\section{CONCLUSION REMARK}

The speech functions occur in the guests' utterances in both in the sensitive topics are statement, question, command, and coffer. However, Command was not found in opponent side. It is advisable for the host and the guests (either speaker or listener) to understand the interpersonal function in the conversation, the speech functions and the mood realization to establish and maintain relationship between the host and the listeners in the conversation. It is worthy to suggest to other researchers to do further studies about interpersonal functions from the other perspective or theories such as gender, culture, and politeness.

\section{REFERENCES}

[1] Arifin, A., \& Samanhudi, U. 2010. Interpersonal Meaning Construction in the Oprah Winfrey Talk Show. International Journal of Leksika. 4(1), 1 13

[2] Bogdan, R. and Biklen, S.K. (1992). Qualitative Research for Education. Boston: Allyn and Bacon

[3] Ezeifeka, C.R. (2014). Critical Discourse Analysis of Interpersonal Meaning and Power Relations in Selected Inaugural Political Speeches in Nigeria. Unizik Journal of Arts and Humanities Vol. 14. Retrieved from: http://www.ajol.info/index.php/ujah/article/view/101194.

[4] Halliday, M.A.K. (1994). An Introduction of Systemic Functional Linguistics. London: Oxford University Press.

[5] .... (2007). Language and Education. London: Continuum

[6] Illie, C. (2006). Talk Shows. Journal of Pragmatics. 15 (10), 180 -232.

[7] Miles, M.B, Huberman, A.M. \& Saldana, J (2014). Qualitative Data Analysis. Expanded. 3rd ed. London: Sage Publications.

[8] Munson, W. (1993). All Talk: The Talk Show In Media Culture. Philadelphia: Temple University Press.

[9] Otten, S. (2010). Discourse Analysis and Functional Grammar in the Classroom: the summary of a Mini-Reading Course. Retrieved from Michigan state University, website:

[10] https://www.msu.edu/ ottensam/954ottenMiniReading.pdf

[11] Timberg, B., \& Erler, R. (2014). Talk Show: Museum of Broadcast Communication. Retrieved from http://www.museum.tv/eotv/talkshows. htm on Saturday 29 November 2014 